\title{
Delisting in Athens Stock Exchange
}

\author{
Yiannis K. Yiannoulis \\ Frederick University, Nicosia and Limassol, Cyprus
}

\begin{abstract}
The scope of this paper is to contribute to the question of delisting (both voluntary and involuntary), with particular emphasis on the initial conditions leading up to the Initial Public Offering (IPO) of the firms. The case of Athens Stock Exchange (ASE) is examined, specifically the IPOs of years 1996-2004 and their subsequent performance (delisting or not) till the end of 2017. We find that the probability of delisting is positively associated with the size of the issuance and the degree of earnings' manipulation and negatively associated with audit quality, information transparency, and market timing. The effects of audit quality, size of issuance, and earnings' manipulation are accentuated in instances of voluntary delisting while the effect of market timing is more clearly pronounced in instances of involuntary delisting. Our results are robust to a number of confounding factors including size, profitability, leverage, liquidity, growth options, and corporate governance. Our work is not replication of existing studies; in addition, we choose ASE as in that capital market there were many delistings the last two decades.
\end{abstract}

Keywords: delisting, Athens Stock Exchange (ASE), Initial Public Offering (IPO), accounting ratios, family form of business, corporate governance, earnings management

\section{Introduction}

Why firms are delisted from a stock exchange? There are many reasons why a company is listed in a stock exchange (for example, easy access to capital and prestige). Several theories have been proposed for the reasons that make companies offer shares to investors in the public equity market (Mikelson, Partch, \& Shah, 1997; Pagano, Panetta, \& Zingales, 1998; Chemmanur \& Fulghieri, 1999; Boot, Gopalan, \& Taylor, 2006; Kim \& Weisbach, 2008; Chemmanur, He, \& Nandy, 2010).

In addition, there is a growing body of corporate governance research that has examined the impact of corporate governance mechanisms on the subsequent Initial Public Offerings (IPO) performance (Balatbat, Taylor, \& Walter, 2004; Chang \& Sun, 2010).

As highlighted by Doidge, Karolyi, and Stulz (2013, p. 547), “...differences in countries’ laws, governance, disclosure and enforcement standards...that protect minority shareholders can explain differences across IPO activity across countries".

However, the phenomenon of delisting is less studied despite its importance; voluntary delisting is linked to firm's corporate governance decision as it is supposed to reduce conflicts of interest and the related agency costs. Delisting is defined as the removal of a listed company from a stock exchange; deregistration or going dark, as

Yiannis K. Yiannoulis, Ph.D. candidate, Lecturer of Accounting and Finance, TEI of Crete, Department of Accounting and Finance, Frederick University, Nicosia and Limassol, Cyprus. 
Martinez and Serve (2016, p. 6) argued, "is a form of delisting that can be defined as a downward step in the firm's listing life". Deregistration is different from a Going Private Transaction (GPT) as "it involves subsequent trading on another market that has fewer restrictions and regulations" (Martinez \& Serve, 2016, p. 6).

Delisting can be realized through different types of transaction: According to Macey, O'Hara, and Pompilio (2008), it is possible to distinguish delisting: (1) merger or acquisition; (2) involuntary delisting when a firm violates exchange rules or experiences financial distress/bankruptcy; and (3) voluntary delisting, GPT or Buy-out Offer with Squeeze-Out (BOSO) (Martinez \& Serve, 2011).

Involuntary and voluntary delistings seem to share the same rationale; some involuntary delisted firms are facing high financial distress costs, while others are no longer able to meet the minimum stock exchange's numerical requirements (i.e., net income level and minimum share price). Voluntary delisted firms are also facing increasing costs, such as agency and/or compliance costs; while the cost rationale is common for both voluntary and involuntary delisting, there is a crucial difference between the two. In voluntary delisting, firms engage in a trade-off; they take the decision to go private in order to avoid listing costs that exceed listing benefits. On the contrary, in the case of involuntary delisting, firms may have gone beyond the point when they can manage costs and are obliged by the market to delist.

The goal of this paper is to review the theoretical and empirical delisting literature and to examine involuntary and voluntary delisting of IPO firms that entered the Athens Stock Exchange (ASE) the period from 1996 to 2004. Specifically, I want to test whether delisted firms have specific corporate governance and IPO characteristics that are unique to them compared to firms that remain listed.

Focusing on a unique, handpicked from original prospectuses, sample of 185 IPOs for the period 1996-2004, I empirically test if incentives acknowledged by academic delisting literature can also be considered for companies listed in the ASE.

I contribute to the existing literature by testing a comprehensive set of potential indicators for involuntary IPO delisting rate; some of them are new, such as information transparency and accounting variables.

My research will contribute to the investigation of a European emerging market, namely Hellas; I will examine institutional changes and listing requirements as well as the delisting of companies on ASE.

In addition, my research will examine whether there is a possibility to predict financial corporate distress using accounting based information from IPO prospectuses; this also will allow us to evaluate the relevance of information contained in the prospectuses in order to predict the delisting status of IPO firms.

Findings from previous studies are beneficial for assessing the Hellenic IPO firms' readiness to go public and for forecasting IPO involuntary delisting, in order to control and reduce involuntary delisting occurrences.

I choose Hellas as it is considered as a "low trust society" with strong interference of state in business and regulation environment (Ballas, Skoutela, \& Tzovas, 2010a; Ballas \& Tzovas, 2010b; Ballas, Hevas, \& Neil, 1998). In addition, financial reporting is linked to taxation (Tzovas, 2006; Baralexis, 2004) and corporate governance follows the insider model with high concentration of ownership, few independent committees, limited disclosure, and weak minority investor protection.

The reason why I choose delisting is because has negative effects on firms and is "accompanied by a sharp decline in stock liquidity, access to finance and corporate transparency" (Bakke, Jens, \& Whithed, 2012, p. 183). 
Macey et al. (2008) studied the effect of delisting from NYSE on the trading shares that end up trading on the "pink sheets"; they provide evidence that shows that firms involuntarily delisted from NYSE experience significant costs after the incidence of delisting. These costs include a post-delisting decline in stock price by approximately half, tripled percentage spreads and doubled volatility compared to when the same stocks were traded on the NYSE.

The rest of the paper is organized as follows: In the next section, I examine the determinants of voluntary and involuntary delisting, while in the third section, I review the literature of IPO delisting. In the forth section, I examine ASE and the related literature on Hellas environment (corporate, accounting, and audit) and in the fifth section, I study the IPO sample and the hypotheses. In the sixth section, the results are discussed, while the seventh section concludes this research

\section{Literature Review}

\section{Voluntary Delisting}

Voluntary delisting raises the question of firms' incentives in order to opt out of a public market; specifically, when a firm decides to go private (squeeze out), this voluntary delisting is referred as "GPT" and is initiated by the existing or new investors ${ }^{1}$. The seminal papers of H. DeAngelo, L. DeAngelo, and Rice (1984) and Lehn and Poulsen (1989) presented the institutional framework for US LBOs and investigated the motivations for these transactions; they found that cost savings is the primary factor for voluntary delisting.

Bharath and Dittmar (2010) argued that because the trade-off between listing costs and benefits explains the decision to go public, this analysis reversibly can also be used to explain why firms decide to exit from a public market. According to these authors, firms decide to delist when the listing costs exceed the benefits of remaining public.

In fact, firms face different trade-offs in their delisting decision depending on the type of voluntary delisting and whether or not they will continue trading afterwards (Bessler, Kaen, \& Kurmann, 2012; Chaplinsky \& Ramchand, 2012).

According to Kim and Weisbach (2008), there are at least three motives (not necessarily mutually exclusive) for listing: (A) to finance investments; (B) to transfer wealth from new shareholders to existing shareholders; and (C) to increase liquidity. On the other hand, going public increases costs; listings costs can be direct and indirect. First, in addition to costs at the IPO stage (registration and underwriting fees), listed firms face standard costs, such as annual listing fees imposed by stock exchanges and trading costs. The indirect costs include: compliance costs (auditing and disclosure) and agency costs; consequently, one reason for going private is to eliminate certain costs (H. DeAngelo et al., 1984; Lehn \& Poulsen, 1989).

As one of the main reasons to go public is the ability to increase liquidity, if that benefit decrease, then the firm will be more likely to voluntary delist (Witmer, 2005).

This liquidity reduction can be due to low financial visibility; indeed, "firms with decrease in analyst

\footnotetext{
1 This transaction can take the form of Leveraged Buy-Out (LBO) where the listed company is acquired by private equity investors using substantial borrowing or by managers (Management Buy-Out [MBO]). In Anglo-Saxon countries (like US and UK) the most common form is LBO, while in European countries the most common is Buy-Out with Squeeze-Out (BOSO). The difference between BOSO and LBO is that a BOSO transaction is initiated by family owners or a corporation and not by private equity investors.
} 
coverage, institutional ownership and turnover are more likely to go private" (Tutino, Panetta, \& Laghi, 2013, p. 219).

Mehran and Peristiani (2010) focused on financial visibility as one important incentive to go private; this is a measure of asymmetric information and is the ability of a firm to attract an adequate level of investor protection and recognition (analyst coverage). Their results showed that firms with decrease in analyst coverage and institutional ownership are more likely to go private.

Financial visibility also reduces the stock price volatility and "enables firms to have a greater bargaining power with banks, resulting in lower borrowing constraints and diversification of sources of financing" (Pour \& Lasfer, 2013, p. 4852).

Another way to assess investor is to examine stock liquidity and the related trading costs. As demonstrated by many studies and models (Amihud \& Mendelson, 1998; Bolton \& Van Thadden, 1998; Boot et al., 2006), the liquidity of share trading is one of the main benefits of going public. As a consequence, if the stock's liquidity deteriorates, then the firm will have an incentive to go private.

Empirical results in the US market (Bharath \& Dittmar, 2010; Mehran \& Peristiani, 2010) and in Europe (Martinez \& Serve, 2011; Achleitner, Betzer, Goergen, \& Hinterramskogler, 2013) supported the strong influence of stock liquidity in the decision to go private.

Voluntary delisting decision leads to higher concentration of share capital as a consequence of share buy-back, increases shareholder's wealth providing rewards for the managers (incentive realignment hypothesis-Kaplan [1989]).

Observing a sample of Going Private Transactions (GPTs) in UK, Weir, Laing, and Wright (2005) and Renneboog, Simons, and Wright (2007) stated that the presence of stronger ownership concentration results in closer monitoring by outside shareholders prior to delisting. Thus, the firm is less likely to suffer from high agency costs originating from possible conflicts of interest between shareholders and managers.

A GPT allows for "reunification" of ownership and control and, as a consequence "will improve the incentive structure and is expected to increase managerial motivations and efforts to maximize firm value" (Reneboog et al., 2007, p. 597).

According to the free cash flow hypothesis, management in a public company has incentives to keep any free cash flow in order to remain flexible and avoid monitoring of bond holders and equity investors (Jensen, 1986). Furthermore, since a relevant free cash flow is attractive for Leveraged Buy-Out (LBO) operation, it can represent a signal for expected GPT; GPT realigns the incentives between management and shareholders through an increasing participation of both to equity.

Another issue under the agency theory is ownership structure; in Continental Europe where ownership is more concentrated ${ }^{2}$, motivation of delisting is closely related to: monitoring role and conflicts of interest between large (mainly family) and minority shareholders. Renneboog et al. (2007) argued that the presence of pre-delisting strong ownership concentration implies that fewer wealth gains are expected of GPTs as the firm is likely to suffer from high agency costs between strong, mainly family, and minority shareholders.

According to Andres, Betzeler, and Weir (2007), the quality of corporate governance before the LBO

${ }^{2}$ According to Faccio and Lang (2002), in Europe, the largest shareholder owns double percentage compared to the Anglo-Saxon LBO targets. 
explains the value gains for shareholders in Europe; firms with weak monitoring by shareholders tend to observe high abnormal returns.

Martinez and Serve (2011) focused on the French market and their results also validated the theoretical incentives identified from the cost-benefit analysis.

Achleitner et al. (2013), observing firm's attractiveness for private equity investors, stated that it depends on the quality of the monitoring by the large shareholder: A better monitored firm is likely to be less attractive to private equity investors as the value-creation potential will be lower. Conversely, in a moderated monitored firm, the large shareholder will be more tempted to sell the firm through an LBO.

Thomsen and Vinten (2007) analyzed the determinants of 3.577 delistings among 12.612 European companies from 21 countries for the years 1995 till 2005; they found that delisted firms were slow-growing, undervalued, and relatively illiquid.

Weir et al. (2005) investigated the driving factors of the delisting decision by comparing characteristics of 111 LBOs of years 1997 till 2001 with those of a random sample of 326 public companies. They found that, unlike firms that remain listed, the delisted firms were: smaller in size, younger, more diversified, and had lower growth opportunities as measured by the $\mathrm{Q}$ ratios.

A study by Boucly, Sraer, and Thesmar (2009) examined 830 French firms that delisted with LBO during the years 1994-2004 by matching these firms with a control group of firms that belong to the same sector but remain listed. They found that smaller firms which are undervalued are the most likely targets.

Another reason of voluntary delisting is the decision to list in a bigger and more prestigious market (Marosi \& Massoud, 2007; Aslan \& Kumar, 2011).

\section{Involuntary Delisting}

Involuntary delisting is happening when a firm experiences financial distress or it violates the stock exchange requirements. Some of the possible violations of listing requirements are: (a) the opening of bankruptcy procedures; (b) low trading volume; (c) negative stock exchange returns; and (d) auditors' opinion.

Yang (2006) studied the reaction of firms that face the threat of involuntary delist; the empirical result showed that firms at risk increased their earnings (earnings management-manipulators).

As involuntary delisting is not the firm's choice, it is mostly accompanied by value destruction; it is regarded as bad news for shareholders and has a negative effect on investor wealth as the share price is diluted after the exit from the stock exchange (Baker \& Kennedy, 2002).

According to Harris, Panchapagesan, and Werner (2008), market quality deteriorates after delisting and the largest decline is associated with delisting due to bankruptcy; they used effective spreads, quoted spreads, trading volume, and volatility and found that trading volume declines more than $50 \%$, reaching $80 \%$ in cases of bankruptcy. In addition quoted and effective spreads as well as volatility triple.

Sanger and Peterson (1990) showed that firm value is negatively affected when the firm is delisted involuntary from NYSE or AMEX; they find that equity values decline by approximately $10 \%$ on the delisting announcement day. According to the authors, this loss of value could be caused by: (1) the decrease in liquidity that follows delisting; and (2) the negative signal regarding the firm's quality.

The study of Chen and Schoderbek (1999) analyses the involuntary delisting process of the AMEX; one of 
the five firms that violated the listing criteria was delisted in the year following the first violation. As some firms violate exchanges requirements without being delisted, the authors suggest that the AMEX does not base the delisting decision on a strict adherence to market rules or financial directives. The following additional criteria were taken into consideration: the start of bankruptcy procedures, lawsuits by shareholders, the volume of exchange, stock returns, and auditor's opinion.

Serrano (2010) compared the enforcement of delisting rules between NYSE-a self-regulated market-and Toronto Stock Exchange (TSX) where delisting rules are mostly defined by a regulatory body. He argues that self-regulation of NYSE amplifies the underlying conflicts of interest; he expected more expensive consequences for investors in firms delisted from NYSE than investors in firms delisted from TSX. According to him, self-regulated exchanges create a suboptimal trading environment due to contradictions in the enforcement of financial market standards.

The literature on involuntary delisting mainly focused on the following areas: (1) examine IPO firms' characteristics that could explain the probability of delisting; (2) study the corporate governance characteristics of involuntary delisted firms compared with a control sample of listed firms; (3) examine the effectiveness of market authorities' control after violation of stock exchange requirements; and (4) inspect firms' strategies to avoid involuntary delisting.

Algebaly, Ibrahim, and Ahmad-Zaluki (2014) examined the determinants of involuntary delisting rate for the Egyptian IPOs over the period 1992-2009. Their sample was divided in two subsamples: The first covers the period from 1992 to 2004, is used to estimate the logit equations, and predicts delisting status of firms of the second subsample which covers the remaining period from 2005 to 2009. Their variables were categorized in the following sections: firm characteristics, offering, signaling, and listing characteristics. Their total sample consisted of 163 IPOs; they find that firm size, ownership structure, financial leverage, asset growth rate, operating efficiency, offering size, and initial return variables are significant determinants of involuntary delisting

Chiraz and Anis (2013) examined the following corporate governance variables: (A) internal (board characteristics, such as independence of board members, board size, and Chief Executive Officer (CEO) and chairman of the board duality); and (B) external (audit firm quality). They used logistic regression and the dependent variable (delisting) takes 1 if the firm was involuntary delisted and 0 otherwise. They found that, although in their sample of 390 French listed companies showed weak corporate governance, corporate governance of delisted firms is weaker. Specifically, for the internal mechanisms, there is a significant negative association between the likelihood of delisting: (i) the proportion of independent directors; and (ii) the size of the board; for external mechanisms the quality of audit firm. In addition, CEO duality increases the likelihood of a company to involuntary delist; however, they find no evidence regarding the presence of independent audit committee.

Li, Zhang, and Zhou (2006) focused on earnings management at the time of the IPO in order to estimate the delisting risk for newly listed firms. They assumed that the magnitude of earnings management at the IPO is inversely correlated with the quality of the firm, which is negatively related with the firm's delisting risk. Their results showed that the need to meet the requirements for an IPO could generate aggressive earnings management; this is related with the delisting risk after the IPO.

The second reason for involuntary delisting is poor operating and financial performance; several empirical 
studies have assessed the probability of aftermarket survival of IPO firms. For example, Seguin and Smoller (1997) examined the delisting of newly listed NASDAQ stocks, distinguishing between two primary determinants: stock market capitalization and stock price. They showed that delisting is related to stock price; specifically, there is higher probability of delisting if stock price is low. After controlling for stock price, they also concluded that market capitalization has additional explanatory power.

Fama and French (2004) analyzed how the changing characteristics of new IPO firms affected whether they survived, merged, or delisted; they showed the importance of firm's deteriorating performance prior to delisting: Almost half of the new IPO firms are delisted within 10 years because of poor performance.

Peristiani and Hong (2004) found that firms with negative pre-IPO performance were three times more likely to delist. Their research focused on predicting the survival rate of firms based on information available to investors; their sample was 9,000 firms listed on USA stock exchanges (NYSE, AMEX, and NASDAQ) for the period 1980-2002. They showed that before the IPO delisted firms are low performers (measured by Return on Assets [ROA]) and also had low capitalization (measured by the equity/assets ratio) compared to the control sample.

Wagner and Cockburn (2010) analyzed the impact of underperformance on the involuntary delisting of Internet and software firms that had completed IPO on NASDAQ in the late 1990s. The authors examined the role of patents in performance and on the probability firms have to go bankrupt-delisted; they assumed that innovating firms have competitive advantage and weak probability of poor performance. For that reason, they expected a positive relationship between patent filing process and the chances of survival. Their results confirmed that relationship; firms without patents exhibit weak performance and a higher risk of being involuntarily delist than firms with patents.

In UK, Espenlaub, Khurshed, and Mohamed (2012) examined the survival of IPOs on the Alternative Investment Market (AIM), a market created to attract young firms with strong growth opportunities but that can not satisfy the regulated market (London Stock Exchange [LSE]) requirements. As a consequence, the explicit listing, regulatory, and disclosure requirements of the AIM are extremely limited and primary oversight is ensured to private entities (NOMinated Advisors [NOMADs]) that are chosen by the firms. Their research used four reputation measures (the NOMAD's market share, credit score, profitability, and age) and created a composite measure for NOMAD reputation based on the average of the NOMAD's percentile ranks for each of the four measures. These measures revealed the significant impact of NOMAD reputation, which can delay the time to delisting from 78 to 103 months; the median survival time is 80 months. In addition, their study revealed the impact of other determinants of survival time, such as: age, size, and insider ownership.

In the same vein, Bhattacharya, Borisov, and Yu (2015) found a positive relationship between IPO survival and the quality of financial intermediaries at the time of the IPO; they also found that both input from venture capitalists, because of their financial and strategic involvement with the firm, and having higher quality underwriters, as they select the best firms, positively affect the survival rate of US IPO firms.

In Continental Europe, the study of Cattaneo, Meoli, and Vismara (2015) focuses on the relationship between regulation and IPO survival in Italy over a very long period (1861-2011); they divided that period in two sub-periods. The first (1974-1997) introduced a new regulation on capital structure in the face of diffuse pressure from financial market agents for less restrictive interventions protecting minority shareholders; the second after 
the "Draghi reform", which was part of the response to a demand for higher investor protection. In line with their hypotheses, they found that IPO survival was higher in the latter period.

In Hellas, Balios, Eriotis, Missiakoulis, and Vasiliou (2015) examined companies listed on ASE and separated them in listed, involuntary delisted, and voluntary delisted; they then estimated a polytomous ordered logit model that incorporated both accounting and market information in order to estimate the probability of remaining listed, voluntary delist (squeeze-out), and involuntary delist.

Their research differs from previous studies as they estimated the same model not only the probability of the company to delist, but the probability to remain listed also. They examined companies listed in 2005, the first year of the IFRS implementation till the end of 2012; their sample was 239 companies, 11 of which were voluntary delisted and 42 were involuntary delisted. Their variables were classified in: (A) accounting (total assets, liquidity-current assets/current liabilities, profitability-net income/sales, years of consecutive losses, and free cash flow); and (B) market variables (free cash flow/assets, stock price change in last year, stock price change in last month, trade volume-logarithm, months without capital raising, and free float percentage).

Their results

provide strong evidence of the impact that leverage, liquidity, trading volume and the performance of stock in the last year have on the probability a company has to remain listed or to be delisted voluntarily or not. Profitability, years of consecutive losses, free cash flows, capital raising and free float do not affect the probability of remaining in or delisting from the market. (Balios et al., 2015, p. 68)

Specifically, liquidity has positive relationship while leverage has negative relationship with delisting; price change and trading volume are significant from the market variables and negatively related with the probability of being delisted. They conclude that "the cut-off points appear insignificant in all cases except the cut-off point between the probabilities of voluntary and nonvoluntary delisting when accounting information is used" (Balios et al., 2015, p. 68).

\section{Hellenic Corporate Governance Environment}

The development of accounting, auditing, and corporate environment in Hellas can be linked to: cultural factors, family structure of business ${ }^{3}$, law, and cultural-political-institutional factors (Ballas, 1994). In this section, I will briefly explain the main developments of the Hellenic environment in terms of capital market, audit, and accounting framework.

\section{Hellenic Corporate and Capital Market (ASE) Environment}

Hellas presented high concentration among the civil law countries, with 67\% ownership (La Porta, Lopez-de-Silanes, Shleifer, \& Vishny, 1999). In a 2001 study of the Hellenic Capital Market Commission (http://www.hcmc.gr), it is stated that ownership dispersion in Hellas is considered middle to low (35.7\% based on shareholders who own less than $1 \%$ of stock and $47.22 \%$ on shareholders who hold less than $5 \%$ ). Thus, the decision-making and administration process are largely controlled by big, mainly family, shareholders; smalland medium- sized enterprises are mainly those that present a family character, while the bigger firms tend to have a higher dispersion (Avlonitis \& Ninassiou, 2001).

\footnotetext{
${ }^{3}$ Family business is common to Continental Europe; what is "unique" in Hellas is that they tend to last only for one generation (Ballas, 1994, p. 120, Note 1).
} 
In addition, Hellenic corporate governance system mainly follows the insider (bank-based) system; specifically, it shows: (A) relatively high concentration by large shareholders, mainly family; (B) few independent committees; (C) limited disclosure, mainly for tax purposes; and (D) weaker investor protection ${ }^{4}$.

The family form is an important and common form of business organization in Hellas; the common feature among most family firms is that the ownership is closely tied to a group of people-the family, which is involved in direct management of the firm (Tsipouri \& Xanthakis, 2004; Spanos, Tsipouri, \& Xanthakis, 2004; Mertzanis, 2001; Mellin \& Nordqvist, 2000; Daily \& Dollinger, 1992). This feature is crucial for the corporate governance analysis of the family firms; Mellin and Nordqvist (2000) defined corporate governance in family firms as "the processes, principles, structures and relationships that help the owner of the firm realize his particular vision, goals and objectives".

As Spanos et al. (2004, p. 5) stated, "The results indicate that competition for control at the company level is low. Large families usually control most of the small and medium sized companies and members of the controlling families are usually serving as the top manager". Large shareholders may act as an effective monitoring mechanism of management and, thereby, could enhance performance; however, controlling blockholders can use their power in order to extract private benefits, at the expense of minority shareholders. This kind of expropriation leads to sub-optimal levels of investment by minority; therefore, the agency problem arises as a conflict between strong blockholders and weak minority owners than between strong managers and weak owners.

As Lazarides (2009, p. 2) stated, "Greece has the same characteristics as Spain, Portugal and other countries that are ranked in the Continental Europe corporate governance system (Franks, Mayer, Volpin, \& Wagner, 2009; Kaufmann, Kraay, \& Mastruzzi, 2009; Shleifer \& Vishny, 1997).

Particular emphasis is given on the actual way with which the owner family exercises its power and influence over the firm; however, family can be a real source of competitive advantage for the firm (Mustakallio \& Valkamo, 2002).

A very common argument favouring family firms is that agency cots are minimized, as the family-owner and management team are the same (Randoy, Jensen, \& Goel, 2003; Fama \& Jensen, 1983; Jensen \& Meckling, 1976).

As Spanos et al. (2004, p. 3) stated,

altruistic behavior and trust can also produce many advantages in the family firm's context e.g. collective ownership by all family members working in the firm, reduction of information asymmetries among family members and commitment of corporate leaders to the firm's long term performance and strategy (Berghe \& Carhon, 2003; De Paola \& Scoppa, 2001; Stark \& Falk, 1998).

However, family firms are associated with high costs and ${ }^{5}$ inefficiencies; for example, as Spanos et al. (2004, p. 3) stated,

confusing family and business matters, family owners could favor family interests over the firm's interests...because

\footnotetext{
${ }^{4}$ La Porta et al. (2002) showed that the degree of investor protection is different around the world due to differences in their legal system. Specifically, common law (Anglo-Saxon such as UK and US) countries have the strongest legal protection for investors, while civil law countries-like Hellas-have the weakest.

5 The prospectuses were in the premises of Athens Stock Exchange. I am very grateful for Mr. Kamaroulis help.
} 
of loyalty towards family... Family firms may encourage internal labour market schemes favouring family members (within-family promotion), rather than competent recruitment processes. Reducing the quality of applicants for executive managerial positions may eventually cause significant monitoring cost.

\section{Hellenic Audit Framework}

According to Ballas (1994, p.116), "Up to 1955 there was no systematic attempt to force an external audit of the financial statements of big private companies; this made oppression of minority shareholders very easy".

Law 3329/1955 introduced the Society of Sworn Accountants (SOL in Greek);

SOL operated in a cartel-like fashion...The numbers of auditors was fixed...Members of SOL enjoyed a very peculiar status. Though SOL was a public sector body, auditors and their assistants were not civil servants but "civil functionaries"...Thus they enjoyed an exceptional degree of professional independence. Furthermore, auditors' fees were non-negotiable and they did not have to go out to search for clients. (Ballas, 1994, pp. 116-117)

In 1991, with Law 1969/1991, it was accepted that the compulsory audit of firms should be conducted by members (individual auditors) of a new body called Society of Sworn Accountants-Auditors (SOEL in Greek). The companies were free to choose their auditor and the audit fee was not fixed any more.

\section{Hellenic Accounting Standards and Profession}

The Hellenic General Accounting Principles (HGAP), with Law 1882/1990, was compulsory for all the companies audited by SOL members (qualified auditors). However, the influence of tax laws in the accounting environment of the companies is still significant:

most of firms continued using tax law regulations even when reporting to their shareholders. The reason was that failure to comply with tax regulations could result in significant penalties, whereas failure to comply with the requirements of the Accounting Plan had practically no effect. (Ballas, 1994, p. 113)

In 2005, the compulsory adoption of International Financial Reporting Standards (IFRS) was compulsory to companies listed in ASE (Spathis \& Georgakopoulou, 2007).

\section{Sample-Hypotheses-Method-Results}

\section{Methodology}

The data we used where handpicked, primary data from original IPO prospectuses of $185 \mathrm{firms}^{5}$; the variables included accounting and IPO characteristics.

The method I used is Propensity Score Matching in order to control of the effect of confounding factors.

\section{Hypotheses}

Audit quality-signalling hypothesis. As Chiraz and Anis (2013, p. 119) stated, "For a sample of non-venture capital-backed microcapitalization IPOs Weber and Willenborg (2003) find that the pre-IPO audit opinions of higher quality auditors are more predictive of post-IPO negative stock delisting". Their rationale was that big audit firms can screen and choose which clients they audit.

Michaely and Shaw (1995) found that more prestigious auditors are associated with less risky IPO firms which are less likely to fail.

In addition, Titman and Trueman (1986) suggested that higher quality firms will employ higher quality auditors in order to signal their quality to the market at the time of their IPO. 
The empirical results of Chiraz and Anis (2013), Chadha (2003), and Demers and Joos (2007) find that IPO firms with high quality auditors are less likely to fail and delist in the long-term.

In addition, Jain and Martin (2005), based on the signaling hypothesis, argued that it is not rational for low-quality firms to take the high quality auditors as this will bring them under the severe monitoring of reputable auditors. This will prohibit them from using earnings management in order to increase investors' valuation regarding their offerings; in addition, low quality firms cannot afford the additional cost of hiring high quality auditors.

In contrast Mangena and Chamisa (2008), using a matched-pairs research design and comparing 81 firms suspended between 1999 and 2005 from South Africa Stock Exchange (Johannesburg Stock Exchange [JSE]), it finds no significant relationship between auditor quality and the likelihood of being delisted.

This leads to the first hypothesis is:

H1: There is a negative relationship between auditor quality and the probability of delisting.

Information transparency proxied by prospectus size. Prospectus size (number of pages) is a new variable, proxy for information transparency; specifically, more pages mean more information audited by underwriters which means more reliable information available to the public.

As Li et al. (2006, p. 6) stated, “...the IPO process is characterized by information asymmetry between managers and investors (e.g., Lelalnd \& Pyle, 1977) and between informs and uninformed investors (e.g., Rock, 1986; Beatty and Ritter, 1986".

The rationale is that if the prospectus has more pages more information is available to the public and information asymmetry is reduced.

So, the second hypothesis is:

$\mathrm{H} 2$ : There is a negative relationship between the size of the prospectus (number pages) and the probability of delisting.

Size of issuance-resource based hypothesis. Based on resource based hypothesis, firms with higher IPO proceeds are expected to survive longer as they are expected to have the required resources for innovation and advertising activities.

Jain and Jayaraman (1999), Willenborg and McKeown (2001), Bhabra and Pettway (2003), Boubakri, Kooli, and L'Her (2005), Kooli and Meknassi (2007), and Algebaly et al. (2014) found a significant negative relationship between offering size and delisting rate.

So, the third hypothesis is:

H3: There is a negative relationship between the probability to delist and IPO proceeds.

Market timing - window of opportunity hypothesis. There is strong support from the literature that IPO activity also significantly contributes to the possibility an IPO firm to be delisted.

As Algebaly et al. (2014, p. 175) claimed,

An IPO is issued either in hot- or cold- issue period; hot-issue periods are the periods within which a large number of IPOs are issued; consequently investors' overoptimism exists. The window of opportunity hypothesis of Ritter (1984, 1991) and Loughran and Ritter (1995) claims that poor-performing firms enter the IPO market in hot-issue periods in order to benefit of investors' overoptimism. Consequently, IPO firms that go public during hot periods are expected to have higher possibility of delisting. 
This expected positive relationship between IPO activity and delisting rate is supported by Boubakri et al. (2005), Demers and Joos (2007), Kooli and Meknassi (2007), and Yung et al. (2008).

Aslan and Kumar (2011, p. 524) stated that "consistent with the strategic marketing hypothesis, namely, that firms attempt to time the market with respect to their IPOs, exploiting not only sectoral mispricing but also market bubbles".

So, the fourth hypothesis is:

H4: There is a positive relationship between IPO activity and the probability of delisting.

Earnings manipulation. Beneish $\mathrm{M}$-score ${ }^{6}$ is a measure of earnings manipulation, as higher values of Beneish (1999) M-Score "imply a greater likelihood that the firm is a manipulator" (Teoh, Wong, \& Rao, 1998, p. 183 ); in response to the delisting risk firms use various strategies, such as earnings management, in order to conceal financial difficulties and delisting.

In the case of deregistrations, Leuz, Triantis, and Wang (2008) highlighted that some firms show lower earnings quality as proxied by accruals.

A similar strategy is analyzed by Yang (2006) who studied firms at risk of involuntary delisting due to violation of stock exchange requirements. She argued that managers have incentives to increase the stock price using earnings management and/or distribution of bonus shares. The results show that firms at risk of being delisted due to violation of numerical standards increased their earnings in order to avoid a decrease in the stock exchange price and allotted bonus shares in order to strengthen the impact on the share prices. In addition, earnings management is statistically more significant in the group of firms that do not distribute bonus shares; earnings management by the firms that are most likely to be delisted is associated with high production of information costs and weak share liquidity.

A recent work by Corcanic and Novak (2015) shows that US firms at risk of being involuntary delisted from NASDAQ increase their stock price and earnings by reporting higher performance-adjusted discretionary accruals. However, the magnitude of earnings management is higher for firms with good future prospects; this indicates that firms manage earnings in order to avoid delisting only when managers believe that they will recover in future.

Li et al. $(2006$, p. 6$)$ argued that

IPOs provide a powerful setting in order to examine the relation between earnings management and delisting risk for two main reasons; first IPO firms have incentives to engage in income-increasing activities to ensure that the issues are fully subscribed. Second the IPO process is characterized by information asymmetry between managers and uninformed investors (e.g., Rock, 1986; Beatty and Ritter, 1986). This information asymmetry provides incentives for managers to engage in earnings management.

So, the fifth hypothesis is:

H5: There is a positive relationship between M-score and the probability of delisting.

Overpricing-Agency theory. "Agency relationship occurs whenever one party hires another one to act on behalf of its interest” (Al-Najjar, 2010, p. 177).

As Ali, Chen, and Radhakrishnan (2006, p. 241) suggested,

\footnotetext{
${ }^{6}$ The variables and the formula in order to calculate Beneish M-Score are explained by Teoh et al. (1998, p. 205, Note 15).
} 
There are two main types of agency problems in public corporations. The first type of agency problem arises from the separation of ownership and management (Type I agency problem). The separation of corporate managers from shareholders may lead to managers not acting in the best interest of the shareholders. The second type of agency problem arises from conflicts between controlling and non-controlling shareholders (Type II agency problem). Controlling shareholders may seek private benefits at the expense of non-controlling shareholders". In Type I agency problem the free rider happens due to "small atomistic shareholders.

To a certain extent, the problem of agency costs can be mitigated by monitoring.

Jensen and Meckling (1976) and Shleifer and Vishny (1997) pointed out that there is a likelihood of principal-agent conflicts when management roles are separated from ownership roles ${ }^{7}$, coupled with the existence of asymmetric information (outsiders have different information compared to insiders). They assert that this is due to the improper use of corporate assets arising from manager's self interest satisfaction in order to pursue projects with high risk, increasing liabilities and reducing current ratio (current assets to current liabilities).

The ratio of Price to Earnings (P/E) is a proxy for overvaluation. As Al-Najjar (2010, p.176) suggested,

The presence of asymmetric information allow managers (the agents to pursue their own objectives that may not be aligned with these of the owners (the principals). Their objective is to increase the share price, increasing the price to earnings and price to book value ratios, by undertaking risky projects with short-term view. However, this increases the probability of delisting.

So, the sixth hypothesis is:

H6: There is a positive relationship between the size of P/E ratio and the probability of delisting.

\section{Model and Sample}

In order for a reliable analysis to be carried out, one should take into account all companies and sectors for a big period. For this reason, I took all IPOs for years $1996^{8}$ till end of 2004. The data were obtained from Hellenic Capital Market Committee (http://www.hcmc) Annual Report and from the original prospectuses of IPO firms.

From that sample I exclude, following previous literature, financial firms ${ }^{9}$ and the remaining number is 185 firms.

From Panel A (Listing status) of Table 1, we see that the half of the sample is delisted firms. In Panel B, we show the industry distribution of the firms and the annual distribution of IPO firms in Panel C; years 1999 and 2000 were the "hot issue" periods.

\footnotetext{
7 According to Al-Najjar (2010, p. 177) "The advantages of such separation include the ability of share ownership without disturbing business operations and the ability to hire managers with special knowledge and skills (Jensen and Meckling, 1976)". ${ }^{8}$ I choose year 1996 as starting year because the renewed Hellenic Capital Market Committee (HCMC, http://www.hcmc.gr) Law regarding IPOs was issued that year. This law as well as the privatization of Hellenic Telecommunication Company (OTE in Greek) was the primary factors that lead to the re-emergence of the Athens Stock Exchange. In addition, December 2004 was the ending point as after that year there were no IPOs in Hellenic stock market.

${ }^{9}$ Financial firms are excluded from the analysis because their financial statements have a special structure and their accounting practices are subject to special regulations (Bhabra \& Pettway, 2003; Jain \& Martin, 2005; Demers \& Joos, 2007).
} 
Table 1

Distribution of IPO Firms

\begin{tabular}{|c|c|c|c|c|c|}
\hline \multicolumn{3}{|l|}{ Panel A: Listing status } & \multicolumn{3}{|c|}{ Panel C: Annual IPO distribution of firms } \\
\hline$\underline{\text { Status }}$ & N. of firms & $\%$ of firms & Year & N. of firms & $\%$ of firms \\
\hline Remain listed & 92 & 49.73 & 1996 & 19 & 10.27 \\
\hline Delisted & $\underline{93}$ & $\underline{50.27}$ & 1997 & 10 & 5.41 \\
\hline Total & 185 & 100 & 1998 & 21 & 11.35 \\
\hline \multirow{2}{*}{\multicolumn{3}{|c|}{ Panel B: Industry representation }} & 1999 & 32 & 17.3 \\
\hline & & & 2000 & 49 & 26.49 \\
\hline Commerce & 56 & 30.27 & 2001 & 17 & 9.19 \\
\hline Construction & 9 & 4.86 & 2002 & 15 & 8.11 \\
\hline General services & 3 & 1.62 & 2003 & 13 & 7.03 \\
\hline Health care & 4 & 2.16 & 2004 & $\underline{9}$ & $\underline{4.86}$ \\
\hline Hotel/Catering & 6 & 3.24 & Total & 185 & 100 \\
\hline I.T.-Real Estate-Rental & 30 & 16.22 & & & \\
\hline Manufacturing & 59 & 31.89 & IPO Activity & $\underline{\text { N. of firms }}$ & $\%$ of firms \\
\hline Primary Sector & 6 & 3.24 & 1996-1998 & \multirow{2}{*}{104} & \multirow{2}{*}{56.22} \\
\hline Transportation & 9 & 4.86 & 2001-2004 & & \\
\hline Utilities & $\underline{3}$ & $\underline{1.62}$ & $1999-2000$ & $\underline{81}$ & $\underline{43.78}$ \\
\hline Total & 185 & 100 & Total & 185 & 100 \\
\hline
\end{tabular}

Notes. Panel A presents the distribution of firms based on their post-IPO status. Panel B presents the distribution of firms by industry. Panel C presents the distribution of firms per year. The term IPO activity identifies two periods of distinct IPO activity: The period including years 1996-1998 and years 2001-2004 is a period of lower IPO activity. The period including years 1999-2000 is a period of higher IPO activity.

Dependent variable (delisting rate). Following previous (Charitou et al., 2007; Demers \& Joos, 2007; Yung et al., 2008) research, delisting rate is a dummy variable that takes the value of "1" if the firm remains delisted within ten years survival time and "0" otherwise.

Control and independent variables. I calculated or took from the audited financial statements in the IPO prospectus of the IPO year:

1. Market Value (logarithm) - MV—(control variable for size used for matching);

2. Total Assets (logarithm)-TA;

3. Sales (logarithm);

4. Debt/Total Assets—D/TA (control variable for gearing used for matching);

5. Current Assets/Current Liabilities-CA/CL (control variable for working capital used for matching);

6. Return on Assets-ROA (control variable for profitability used for matching);

7. Return on Equity-ROE;

8. Market Value/Book Value-M/B (control variable for growth used for matching);

9. Price/Earnings-P/E (HYPOTHESIS 6th);

10. IPO age-how many years after incorporation the company had IPO;

11. IPO proceeds (logarithm) - IPO Proc-Stock price $\times$ number of IPO shares (Hypothesis $3 \mathrm{rd}$ );

12. Board size—number of Board members (control variable for corporate governance);

13. Prospectus size-number of IPO prospectus pages (Hypothesis 2nd);

14. M-Score-a proxy for earnings manipulation (Teoh et al., 1998, p. 183 and Note 15, p. 205) (Hypothesis 5th). 
Table 2

Descriptive Statistics of IPO Firms for the Period 1996-2004

\begin{tabular}{llllllll}
\hline Variables & Mean & Std dev & 5th Pctl & 25th Pctl & Median & 75th Pctl & 95th Pctl \\
\hline $\ln (\mathrm{MV})$ & 17.74 & 1.39 & 15.97 & 16.68 & 17.54 & 18.41 & 20.48 \\
$\ln (\mathrm{TA})$ & 17.35 & 1.24 & 15.83 & 16.45 & 17.12 & 17.87 & 19.76 \\
$\ln$ (Sales) & 16.91 & 1.43 & 15.31 & 16.09 & 16.60 & 17.58 & 19.64 \\
D/TA & 0.42 & 0.20 & 0.11 & 0.26 & 0.42 & 0.57 & 0.71 \\
CA/CL & 2.11 & 1.27 & 0.82 & 1.29 & 1.74 & 2.49 & 5.20 \\
ROA & 0.11 & 0.07 & 0.04 & 0.06 & 0.09 & 0.14 & 0.25 \\
ROE & 0.23 & 0.25 & 0.05 & 0.12 & 0.17 & 0.25 & 0.63 \\
M/B & 3.94 & 6.23 & 1.10 & 1.93 & 2.62 & 4.08 & 9.25 \\
P/E & 22.70 & 21.27 & 5.84 & 9.77 & 14.50 & 28.39 & 62.27 \\
IPO age & 16.43 & 11.79 & 4.00 & 8.00 & 14.00 & 22.00 & 37.00 \\
ln (IPO Proc) & 15.61 & 1.44 & 13.69 & 14.39 & 15.49 & 16.47 & 18.29 \\
Board size & 6.62 & 2.84 & 4.00 & 5.00 & 6.00 & 7.00 & 11.00 \\
Prospectus size & 166.15 & 83.37 & 70.00 & 106.00 & 140.00 & 211.50 & 327.00 \\
M-Score & -1.41 & 5.83 & -3.58 & -1.52 & -0.84 & -0.08 & 1.26 \\
\hline
\end{tabular}

Notes. $\ln (M V)$ is the natural log of market capitalization defined as market price times number of shares outstanding. $\ln (T A)$ is the natural log of total assets. In (Sales) is the natural log of total sales. D/TA is the ratio of total debt over total assets. CA/CL is the current ratio defined as current assets over current liabilities. ROA is return on assets defined as net income over total assets. ROE is return on equity defined as net income over shareholder equity. $M / B$ is the ratio of market value over book value of equity. $P / E$ is the ratio of stock price over net income per share. IPO Age is the number of years between the company's year of incorporation and the IPO year. In (IPO Proc) is the is natural log of the total IPO proceeds. Board Size is the number of board members. Prospectus Size is the number of pages comprising the firm IPO prospectus. M-Score corresponds to the Beneish (1999) model for the likelihood that the firm is an earnings manipulator.

\section{Results}

\section{Propensity Score Matching (PSM)}

Then, I examine the correlation of control variables that will be used in Propensity Score Matching (see Table 4).

The control variables I use in order to match listed and delisted firms are:

1. $\ln (\mathrm{MV})$ - proxy for size;

2. ROA-proxy for profitability;

3. D/TA-proxy for size;

4. $\mathrm{CA} / \mathrm{CL}-$ proxy for working capital;

5. M/B-proxy for overvaluation or growth;

6. Board size-proxy for corporate governance quality. ${ }^{10}$

As Mangena and Chamisa (2008, p. 38) argued, "A major concern in regression analysis is the problem of multicollinearity among the independent variables". From Table 3, we see that all correlations are below 0.7 which is considered a threshold (Mangena \& Chamisa, 2008, p. 38).

\footnotetext{
${ }^{10}$ The law that obliged listed companies to have independent committees was applicable for years after 2002 (i.e., 2003 and after).
} 
Table 3

Correlation Matrix

\begin{tabular}{|c|c|c|c|c|c|c|}
\hline \multicolumn{7}{|c|}{$\begin{array}{l}\text { Pearson/Spearman correlation coefficients } \\
\text { Prob }>|r| \text { under H0: Rho }=0\end{array}$} \\
\hline & $\ln (\mathrm{MV})$ & $\mathrm{ROA}$ & $\mathrm{D} / \mathrm{TA}$ & $\mathrm{CA} / \mathrm{CL}$ & $\mathrm{M} / \mathrm{B}$ & Board size \\
\hline $\ln (\mathrm{MV})$ & 1 & $\begin{array}{l}0.11 \\
(0.15)\end{array}$ & $\begin{array}{l}-0.13 \\
(0.08)\end{array}$ & $\begin{array}{l}0.14 \\
(0.06)\end{array}$ & $\begin{array}{l}0.24 \\
(0.00)\end{array}$ & $\begin{array}{l}0.48 \\
<0.0001\end{array}$ \\
\hline ROA & $\begin{array}{l}-0.06 \\
(0.39)\end{array}$ & 1 & $\begin{array}{l}-0.03 \\
(0.72)\end{array}$ & $\begin{array}{l}-0.08 \\
(0.28)\end{array}$ & $\begin{array}{l}0.42 \\
<0.0001\end{array}$ & $\begin{array}{l}0.11 \\
(0.19)\end{array}$ \\
\hline $\mathrm{D} / \mathrm{TA}$ & $\begin{array}{l}-0.16 \\
(0.03)\end{array}$ & $\begin{array}{l}-0.15 \\
(0.05)\end{array}$ & 1 & $\begin{array}{l}-0.72 \\
<0.0001\end{array}$ & $\begin{array}{l}0.24 \\
(0.00)\end{array}$ & $\begin{array}{l}-0.14 \\
(0.08)\end{array}$ \\
\hline $\mathrm{CA} / \mathrm{CL}$ & $\begin{array}{l}0.13 \\
(0.07)\end{array}$ & $\begin{array}{l}0.08 \\
(0.29)\end{array}$ & $\begin{array}{l}-0.75 \\
<0.0001\end{array}$ & 1 & $\begin{array}{l}-0.14 \\
(0.05)\end{array}$ & $\begin{array}{l}0.03 \\
(0.70)\end{array}$ \\
\hline $\mathrm{M} / \mathrm{B}$ & $\begin{array}{l}0.48 \\
<0.0001\end{array}$ & $\begin{array}{l}0.22 \\
(0.00)\end{array}$ & $\begin{array}{l}0.12 \\
(0.11)\end{array}$ & $\begin{array}{l}-0.06 \\
(0.45)\end{array}$ & 1 & $\begin{array}{l}0.01 \\
(0.93)\end{array}$ \\
\hline Board size & $\begin{array}{l}0.41 \\
<0.0001\end{array}$ & $\begin{array}{l}0.08 \\
(0.31)\end{array}$ & $\begin{array}{l}-0.15 \\
(0.07)\end{array}$ & $\begin{array}{l}0.02 \\
(0.80)\end{array}$ & $\begin{array}{l}0.03 \\
(0.67)\end{array}$ & 1 \\
\hline
\end{tabular}

Notes. Coefficients above the unit diagonal correspond to Pearson correlation statistics. Coefficients below the unit diagonal correspond to Spearman Rank non-parametric correlation statistics. $P$-values under the null hypothesis of zero correlation are reported in brackets for both methods.

In Propensity Score Matching, we have 82 treated observations and 70 controls and 70 matched pairs, as described in Table 4, Panel A; I use the greedy matching method in order to match the observations in the sample.

Table 4

Propensity Score Matching

\begin{tabular}{|c|c|c|c|c|c|c|}
\hline \multicolumn{7}{|c|}{ Panel A: Propensity score matching information } \\
\hline \multicolumn{2}{|c|}{ Treatment variable } & \multicolumn{2}{|l|}{ Listing status } & Distance metric & \multicolumn{2}{|c|}{ Logit of propensity score } \\
\hline \multicolumn{2}{|l|}{ All Obs. } & \multicolumn{2}{|l|}{185} & Method & \multicolumn{2}{|c|}{ Greedy Matching (Knn) } \\
\hline \multicolumn{2}{|l|}{ All Obs. (Treated) } & \multicolumn{2}{|l|}{82} & Control/Treated ratio & \multicolumn{2}{|c|}{$1(k=1)$} \\
\hline \multicolumn{2}{|c|}{ All Obs. (Control) } & \multicolumn{2}{|l|}{70} & Caliper & \multicolumn{2}{|l|}{0.5} \\
\hline \multicolumn{2}{|c|}{ All Obs. (Sup. region) } & \multicolumn{2}{|l|}{70} & Lower PS support & \multicolumn{2}{|l|}{0.144024} \\
\hline Matched pairs & & 70 & & & & \\
\hline \multicolumn{7}{|c|}{ Panel B: Mean/Standardized differences (treated-control) } \\
\hline Variables & Observations & $\begin{array}{l}\text { Mean } \\
\text { difference }\end{array}$ & $\begin{array}{l}\text { Standard } \\
\text { deviation }\end{array}$ & $\begin{array}{l}\text { Standardized } \\
\text { difference }\end{array}$ & $\begin{array}{l}\text { Percent } \\
\text { reduction }\end{array}$ & $\begin{array}{l}\text { Variance } \\
\text { ratio }\end{array}$ \\
\hline \multirow{2}{*}{ Logit prop score } & All & 0.97 & 2.10 & 0.46 & & 18.81 \\
\hline & Matched & 0.47 & & 0.22 & 51.68 & 0.67 \\
\hline \multirow{2}{*}{$\ln (\mathrm{MV})$} & All & 0.48 & 1.37 & 0.35 & & 1.02 \\
\hline & Matched & 0.47 & & 0.34 & 2.14 & 0.81 \\
\hline \multirow{2}{*}{ ROA } & All & 0.01 & 0.07 & 0.15 & & 1.07 \\
\hline & Matched & 0.01 & & 0.07 & 53.80 & 0.67 \\
\hline \multirow{2}{*}{$\mathrm{D} / \mathrm{TA}$} & All & -0.04 & 0.20 & -0.19 & & 0.91 \\
\hline & Matched & -0.06 & & -0.29 & 0.00 & 0.88 \\
\hline \multirow{2}{*}{$\mathrm{CA} / \mathrm{CL}$} & All & 0.18 & 1.31 & 0.14 & & 1.30 \\
\hline & Matched & 0.33 & & 0.25 & 0.00 & 1.39 \\
\hline \multirow{2}{*}{$\mathrm{M} / \mathrm{B}$} & All & 1.43 & 6.43 & 0.22 & & 8.40 \\
\hline & Matched & 0.83 & & 0.13 & 42.01 & 2.68 \\
\hline \multirow{2}{*}{ Board size } & All & 0.43 & 2.80 & 0.15 & & 2.06 \\
\hline & Matched & 0.23 & & 0.08 & 47.01 & 1.34 \\
\hline
\end{tabular}


Notes. Panel A gives information regarding the propensity matching routine. The Treatment Variable is Listing Status as defined in Table 2. The Support Region gives the number of observation in which the minimum distance of propensity scores for matching is satisfied. The Distance Metric specifies the first stage logit regression for extracting propensity scores. The Method specifies the matching algorithm as k-nearest neighbors (with no replacement). Control/Treated Ratio specifies that ratio or treated/controlled matches. The Caliper $=0.5$ specifies that the difference in the logits of the propensity scores for pairs of individuals from the two groups must be less than or equal to 0.5 times the pooled estimate of the common standard deviation of the logits of the propensity scores. The Lower PS Support specifies the minimum propensity score in the support region. Panel B presents the standardized differences between the treated and control groups for all observations and the matched observations. The overall percent reduction of standardized differences after matching is $52.68 \%$. All variables are defined in Table 1 . The presentation of results regarding individual variables omits industry dummy variables for brevity.

\section{Univariate and Multivariate Logistic Regressions}

The logistic regression in the first six (i.e., 1-6) models is each variable alone, while in seven till 11, we add a variable each time. The highest Pseudo $R^{2}$ is given by the 11 th (XI) model.

Table 5

Logistic Regression Analysis: Listed vs. Delisted

\begin{tabular}{|c|c|c|c|c|c|c|c|c|c|}
\hline & $\begin{array}{l}\text { (A) } \\
\text { Aud_Q }\end{array}$ & $\begin{array}{l}\text { (B) } \\
\text { Prosp_S }\end{array}$ & $\begin{array}{l}\text { (C) } \\
\text { IPO Proc }\end{array}$ & $\begin{array}{l}\text { (D) } \\
\text { IPO_Act }\end{array}$ & $\begin{array}{l}\text { (E) } \\
\text { M-Scr }\end{array}$ & $\begin{array}{l}\text { (F) } \\
P / E\end{array}$ & $\begin{array}{l}(\mathrm{A}) \times(\mathrm{B}) \\
\text { IntR1 }\end{array}$ & $\begin{array}{l}(\mathrm{D}) \times(\mathrm{E}) \\
\mathrm{IntR2}\end{array}$ & $\operatorname{Psd} R^{2}(\%)$ \\
\hline (1) & $\begin{array}{l}-0.48 \\
(0.35)\end{array}$ & & & & & & & & 1.83 \\
\hline (2) & & $\begin{array}{l}0.19^{* * *} \\
(0.06)\end{array}$ & & & & & & & 6.45 \\
\hline (3) & & & $\begin{array}{l}0.17 \\
(0.24)\end{array}$ & & & & & & 0.48 \\
\hline (4) & & & & $\begin{array}{l}-0.81^{* *} \\
(0.34)\end{array}$ & & & & & 5.27 \\
\hline (5) & & & & & $\begin{array}{l}0.26 \\
(0.44)\end{array}$ & & & & \\
\hline (6) & & & & & & $\begin{array}{l}-0.00 \\
(0.85)\end{array}$ & & & 0.03 \\
\hline (7) & $\begin{array}{c}-0.57^{*} \\
(0.36)\end{array}$ & $\begin{array}{l}0.19^{* * *} \\
(0.06)\end{array}$ & & & & & & & 9.94 \\
\hline (8) & $\begin{array}{l}-0.53^{*} \\
(0.36)\end{array}$ & $\begin{array}{l}0.22^{* * *} \\
(0.07)\end{array}$ & $\begin{array}{l}0.38 \\
(0.28)\end{array}$ & & & & & & 11.7 \\
\hline (9) & $\begin{array}{l}-0.62^{*} \\
(0.37)\end{array}$ & $\begin{array}{l}0.17^{* *} \\
(0.07)\end{array}$ & $\begin{array}{l}0.58^{*} \\
(0.30)\end{array}$ & $\begin{array}{l}-0.84^{* *} \\
(0.42)\end{array}$ & & & & & 15.3 \\
\hline (10) & $\begin{array}{l}-0.64^{*} \\
(0.38)\end{array}$ & $\begin{array}{l}0.54 \\
(0.39)\end{array}$ & $\begin{array}{l}0.63^{* *} \\
(0.31)\end{array}$ & $\begin{array}{l}-1.37^{* * *} \\
(0.44)\end{array}$ & $\begin{array}{l}0.84^{*} \\
(0.51)\end{array}$ & & & & 13.62 \\
\hline (11) & $\begin{array}{l}-0.67^{*} \\
(0.38)\end{array}$ & $\begin{array}{l}0.46 \\
(0.39)\end{array}$ & $\begin{array}{l}0.62^{* *} \\
(0.30)\end{array}$ & $\begin{array}{l}-1.55^{* * *} \\
(0.50)\end{array}$ & $\begin{array}{l}0.85^{*} \\
(0.52)\end{array}$ & $\begin{array}{l}0.01 \\
(0.01)\end{array}$ & & & 14.2 \\
\hline (12) & $\begin{array}{l}-0.05 \\
(0.84)\end{array}$ & $\begin{array}{l}1.31^{* *} \\
(0.63)\end{array}$ & $\begin{array}{l}0.58^{*} \\
(0.30)\end{array}$ & $\begin{array}{l}-1.74^{* * *} \\
(0.53)\end{array}$ & $\begin{array}{l}0.86^{*} \\
(0.52)\end{array}$ & $\begin{array}{l}0.01 \\
(0.01)\end{array}$ & $\begin{array}{l}-1.42^{*} \\
(0.81)\end{array}$ & & 16.9 \\
\hline (13) & $\begin{array}{l}-0.58^{*} \\
(0.11)\end{array}$ & $\begin{array}{l}0.53 \\
(0.38)\end{array}$ & $\begin{array}{l}0.43^{*} \\
(0.28)\end{array}$ & & & $\begin{array}{l}0.00 \\
(0.01)\end{array}$ & & $\begin{array}{l}-0.96^{* * *} \\
(0.47)\end{array}$ & 9.0 \\
\hline
\end{tabular}


Notes. Table 5 presents results from logistic regressions. The dependent variable is probability of delisting. Aud_Q represents audit quality and is defined as 1 for auditors that belong to the "big-5" audit firms or to the Hellenic Association of Auditors (SOL in Greek) and 0 otherwise. Prosp_S is the natural log of the number of pages comprising the IPO prospectus scaled by size. IPO ProC is the natural $\log$ of IPO proceeds scaled by market value. IPO_Act is a dummy equal to 1 for years 1999-2000 and 0 otherwise. $M$-Score is a dummy equal to 1 if the m-score estimated from the Beneish (1999) model is greater than -1.89 , zero otherwise. $P / E$ ratio is the ratio of price over earnings per share measured using the closing price of the IPO. IntR1 is an interactive term capturing the combined effect of a large prospectus and higher audit quality. Int $R^{2}$ is an interactive term capturing the combined effect of higher IPO activity and higher P/E ratios. The superscripts ${ }^{* * *}\left(^{* *}\right)\left(^{*}\right)$ denote statistical significance at $1 \%(5 \%)(10 \%)$ correspondingly. The significance statistics correspond to the Wald Chi-Square test. Standard errors are reported in brackets.

From the univariate and multivariate regressions is found that: (1) There is a negative relationship between audit quality and the probability of delisting; (2) there is a positive relationship with prospectus size and the probability of delisting; (3) there is a positive relationship between IPO proceeds and the probability of delisting; (4) there is a positive relationship between IPO activity and the probability of delisting; (5) there is a positive relationship with M-Score and IPO activity; and (6) there is no relationship between Price to Earnings (P/E) ratio and the probability of delisting.

The only hypotheses that have different sign than expected are the second, the third and the sixth.

The results on audit quality differ from the ones of Mangena and Chamisa (2008) who find not significant relation.

\section{Involuntary Versus Voluntary Delisted}

In Table 6, a comparison of involuntary and voluntary delisting is examined. We find that the effects of audit quality, size of issuance, and earnings' manipulation are accentuated in instances of voluntary delisting while the effect of market timing is more clearly pronounced in instances of involuntary delisting.

Table 6

Multinomial Logit: Listed vs. Involuntary Delisted vs. Voluntary Delisted (Reference Group: Remain Listed)

\begin{tabular}{|c|c|c|c|c|c|c|c|c|c|c|}
\hline \multicolumn{6}{|c|}{ Panel A: Analysis of coefficients } & \multicolumn{5}{|c|}{ Panel B: Odds ratio estimates } \\
\hline & \multicolumn{2}{|l|}{ All firms } & \multirow{2}{*}{$\begin{array}{l}\begin{array}{l}\text { Involuntary } \\
\text { delisted }\end{array} \\
\text { (III) } \\
\end{array}$} & \multirow{2}{*}{$\begin{array}{l}\begin{array}{l}\text { Voluntary } \\
\text { delisted }\end{array} \\
\underline{\text { IV })}\end{array}$} & \multirow{2}{*}{$\begin{array}{l}\text { Diff. } \\
(\mathrm{V})\end{array}$} & \multicolumn{2}{|c|}{$\begin{array}{l}\text { Involuntary } \\
\text { delisted }\end{array}$} & & \multicolumn{2}{|c|}{$\begin{array}{l}\text { Voluntary } \\
\text { delisted }\end{array}$} \\
\hline \multirow[t]{2}{*}{ Column } & $\underline{\text { (I) }}$ & $\underline{\text { (II) }}$ & & & & $\underline{(\mathrm{VI})}$ & (VII) & & (VIII) & $\underline{(\mathrm{IX})}$ \\
\hline & $\underline{\text { Coeff (b) }}$ & $\frac{\text { Type } 3}{\text { Effects }}$ & $\underline{\operatorname{Coeff}\left(b^{\text {inv }}\right)}$ & $\underline{\text { Coeff }\left(b^{v o l}\right)}$ & $\left(b^{\text {inv }}-b^{\text {vol }}\right)$ & $\frac{\operatorname{Exp}}{\left(b^{\text {inv }}\right)}$ & $95 \% \mathrm{~V}$ & ald CIL & $\frac{\operatorname{Exp}}{\left(\mathrm{b}^{\mathrm{vol}}\right)}$ & 95\% Wald CIL \\
\hline \multirow[t]{2}{*}{ Aud_Q } & -0.12 & & -0.55 & $-1.15^{*}$ & $0.60^{*}$ & 0.58 & $(0.18$ & 1.91) & 0.32 & $(0.09,1.09)$ \\
\hline & $(-0.51)$ & $6.44^{* *}$ & $(0.61)$ & $(0.63)$ & $(2.72)$ & & & & & \\
\hline \multirow[t]{2}{*}{ Prosp_S } & $1.28^{* *}$ & & 0.59 & 1.04 & $-0.45^{*}$ & 1.80 & $(0.41$ & 7.94) & 2.82 & $(0.70,11.44)$ \\
\hline & $(-0.63)$ & $4.77^{*}$ & $(0.76)$ & $(0.71)$ & $(3.43)$ & & & & & \\
\hline \multirow[t]{2}{*}{ IPO Proc } & $0.52^{*}$ & & 0.11 & $1.06^{* * *}$ & $-0.95^{* *}$ & 1.12 & $(0.58$ & 2.14) & 2.88 & $(1.25,6.64)$ \\
\hline & $(-0.3)$ & $5.87^{* *}$ & $(0.33)$ & $(0.43)$ & $(4.48)$ & & & & & \\
\hline \multirow[t]{2}{*}{ IPO_Act } & $-1.49^{* * *}$ & & $-1.35^{* *}$ & $-1.21^{* *}$ & -0.14 & 0.26 & $(0.09$ & $0.77)$ & 0.30 & $(0.10,0.90)$ \\
\hline & $(-0.48)$ & $4.58^{*}$ & $(0.56)$ & $(0.57)$ & $(0.03)$ & & & & & \\
\hline \multirow[t]{2}{*}{$\mathrm{P} / \mathrm{E}$} & 0.01 & & 0.01 & 0.00 & 0.01 & 1.01 & (0.99, & 1.04) & 1.00 & $(0.98,1.03)$ \\
\hline & $(-0.01)$ & 2.37 & $(0.01)$ & $(0.01)$ & $(1.18)$ & & & & & \\
\hline \multirow[t]{2}{*}{ IntR1 } & $-1.39^{* *}$ & & -0.66 & -0.73 & 0.07 & 0.52 & $(0.49$ & $0.48)$ & 0.48 & $(0.08,3.10)$ \\
\hline & $(-0.8)$ & 1.75 & $(0.94)$ & $(0.95)$ & $(1.52)$ & & & & & \\
\hline
\end{tabular}


Notes. Table 6 presents results from a multinomial logit regression with three outcome groups: Remain Listed (1), Involuntary Delisted (2), and Voluntary Delisted (3). The reference group is Remain Listed (1). All explanatory variables are as defined in table 5. Panel A presents the analysis of maximum likelihood coefficients. Column (I) repeats the coefficients of a logistic regression in which Involuntary and Voluntary Delisted firms are clustered into a single group. Standard errors from the Wald $x^{2}$ test are reported in parentheses. The superscripts $* * *(* *)(*)$ denote statistical significance at $1 \%(5 \%)(10 \%)$ correspondingly. Column (II) the overall significance of the explanatory variables when the logistic regression is estimated simultaneously Groups 2 and 3 . Columns (III) and (IV) presents separate coefficients for each group. Column (V) tests for statistical significance of effects in-between Groups 2 and 3. Panel B presents the odds ratio estimates. Column (VI) presents the point estimates for Group 2 while Column (VIII) presents the point estimates for Group 3. Columns (VII) and (IX) present the $95 \%$ Wald $x^{2}$ confidence intervals.

\section{Conclusion}

In this paper, I examine the IPO delisting phenomenon in Hellenic Stock Exchange (Athens Stock Exchange [ASE], ATHEX, http://www.helex.gr). I contribute to the existing literature by testing a comprehensive set of potential indicators for the IPO delisting rate; some of them are new, such as prospectus size. In addition, several theories are tested in this study, namely, agency cost, signalling, and resource based theory.

The reason for the importance of the examination of IPO survival of that specific exchange is that from 1996 till 2004 the total number of new listings was 194 firms. From these, only 107 are still listed (about half) as of December 2016, while the rest are either: delisted (41 firms), merged with listed (25 firms), and merged with delisted (20 firms).

The reason for examining IPO companies is that these companies suffer the cost of being monitored by outsiders (i.e., investment banks, auditors, analysts, and investors). In addition, IPOs: (A) make firm shares more liquid which increases firm value; (B) allows firms to improve their financial position through issuing new shares, (C) enhance corporate image; (D) increase employees' motivation; and (E) diversify current shareholders' portfolios.

However, there are some costs associated with listing, such as: (A) Listed firm is losing control over information; (B) firm suffers the costs of audit, committees and non-executive directors; and (C) previous shareholders are losing their power and they share firm's profits with the new/after-IPO investors.

The reason I examined delisting is that it has negative effects on firms and is "accompanied by sharp decline in stock liquidity, access to finance and corporate transparency” (Bakke et al., 2012, p. 183).

The reasons why I examine only Hellas are: (1) Hellas IPO delisting is not examined before till now (Balios et al. 2015 examined delisting in general and not specifically of IPOs like current study); and (2) "due to country differences it is desirable and warranted that "various governance structures should be separately examined in each country" (Vafeas \& Theodorou, 1998, p. 384).

This would enable the evidence on the efficacy of governance mechanisms to be generalized across countries.

Given these high costs associated with delisting, understanding its economic determinants becomes an important question. According to Thomsen and Vinten (2007, p. 7), "insolvency implies that a company cannot repay its debt due to lack of liquidity (Altman, 1968, 1993; Schary, 1991; Bechetti \& Sierra, 2004; Buehler, Kaiser, \& Jaeger, 2006). This may or may not ultimately lead to bankruptcy".

To sum up, there are strong differences across countries with regard to the enforcement of delisting rules in stock market, as regulated markets are generally unlike controlled markets in this respect. Europe is very different 
from USA because delisting is handled by the regulator (i.e., in UK the decision is taken by a private entity-Financial Service Authority (FSA) - in France, as well as in Hellas the decision is taken by a public entity. Thus, depending on their nature (i.e., whether they are regulated or self-regulated), the markets remain different in their capacity to ensure liquidity and offer investor protection.

While the study produces important results it has, however, some limitations. First, we examined only IPO variables and not corporate governance (board size and board duality). The reason is that corporate governance was introduced in ASE with Law 3016/2002 and was compulsory for all listed firms from 2003 and not before. It would be useful to examine the effect of corporate governance code to the incidence of delisting and compare that effect before and after the Law 3016/2002.

Second, the method of propensity score matching is used while other studies use matched pair analysis (Mangena \& Chamisa, 2008).

\section{References}

Achleitner, A. K., Betzer, A., Goergen, M., \& Hinterramskogler, B. (2013). Private equity acquisitions of continental European firms: The impact of ownership and control on the likelihood of being taken private. European Financial Management, 19, 72-107.

Algebaly, E. A. M., Ibrahim, Y., \& Ahmad-Zaluki, N. A. (2014). The determinants of involuntary delisting rate in the Egyptian stock market. Review of Accounting and Finance, 13(2), 171-190.

Al-Najjar, B. (2010). Corporate governance and institutional ownership: Evidence from Jordan. Corporate Governance: The International Journal of Business in Society, 10(2), 176-190.

Ali, A., Chen, T. Y., \& Radhakrishnan, S. (2006). Corporate disclosures by family firms. Retrieved 24/5/2018 from https://ssrn.com/abstract=897817

Altman, E. I. (1968). Financial Ratios, discriminant analysis and the prediction of corporate bankruptcy. Journal of Finance, 23(4), 589-609.

Altman, E. I. (1993). Corporate financial distress and bankruptcy. New York, USA: John Wiley and Sons.

Amihud, Y., \& Mendelson, H. (1998). Illiquidity and stock returns cross-section and time series effects. Journal of Financial Markets, 5, 31-56.

Andres, C., Betzeler, A., \& Weir, C. (2007). Shareholder wealth gains through better corporate governance-The case of European LBO-transactions. Financial Markets Portfolio Management, 21, 403-424.

Aslan, H., \& Kumar, P. (2011). Lemons or cherries? Growth opportunities and market temptations in going public and private. Journal of Financial and Quantitative Analysis, 46, 489-526.

Avlonitis, X., \& Ninassiou, A. (2001). The level of ownership dispersion in Greek listed companies. Hellenic Capital Market Commission. Retrieved 24/5/2018 from http://www.hcmc.gr

Baker, G. P., \& Kennedy, R. E. (2002). Survivorship and the economic grim reaper. The Journal of Law, Economics and Organization, 18(2), 324-361.

Bakke, T., Jens, C., \& Whithed, T. (2012). The real effects of delisting: Evidence from a regression discontinuity design. Finance Research Letters, 9, 183-193.

Balatbat, M. C., Taylor, S. L., \& Walter, T. S. (2004). Corporate governance, insider ownership and operating performance of Australian initial public offerings. Accounting and Finance, 44, 299-328.

Balios, D., Eriotis, N., Missiakoulis, S., \& Vasiliou, D. (2015). Delisted versus voluntary delisted versus remain listed: An ordered analysis. Applied Economic Letters, 22(1), 66-70.

Ballas, A. (1994). Accounting in Greece. European Accounting Review, 3(1), 107-121.

Ballas, A., Hevas, A., \& Neil, D. (1998). The state of the accounting and the state of the state. Journal of Management and Governance, 2, 267-285.

Ballas, A., Skoutela, D., \& Tzovas, C. (2010a). The relevance of IFRS to an emerging market: Evidence from Greece. Managerial Finance, 36(11), 931-948. 
Ballas, A., \& Tzovas, C. (2010b). An empirical investigation of Greek firms' compliance to IFRS disclosure requirements. International Journal of Managerial and Financial Accounting, 2, 40-62.

Baralexis, S. (2004). Creative accounting in small advancing countries: The Greek case. Managerial Auditing Journal, 19(3), 440-461.

Beatty, R. P., \& Ritter, J. R. (1986). Investment banking, reputation and the underpricing of initial public offerings. Journal of Financial Economics, 15, 213-232.

Bechetti, L., \& Sierra, J. (2004). Bankruptcy risk and productive efficiency in manufacturing firms. Journal of Banking and Finance, 27, 2099-2120.

Beneish, M. (1999). The detection of earnings manipulation. Retrieved from http://citeseerx.ist.psu.edu/viewdoc/download?doi=10.1.1.195.3676\&rep=rep1\&type=pdf

Berghe, L. A. A., \& Carchon, S. (2003). Agency relations within the family business system: An explanatory approach. Corporate Governance: An International Review, 11(3), 171-179.

Bessler, W., Kaen, F. R., \& Kurmann, P. (2012). The listing and delisting of German firms on NYSE and NASDAQ: Were there any benefits. Journal of International Financial Markets, Institutions and Money, 22, 1024-1053.

Bhabra, H., \& Pettway, R. (2003). IPO prospectus information and subsequent performance. Financial Review, 38(3), $369-397$.

Bharath, S. T., \& Dittmar, A. K. (2010). Why do firms use private equity to opt out of public markets? Review of Financial Studies, 23, 1771-1818.

Bhattacharya, U., Borisov, A., \& Yu, X. (2015). Firm mortality and Natal financial care. Journal of Financial and Quantitative Analysis, 50, 61-88.

Bolton, P., \& Van Thadden, E. L. (1998). Liquidity and control: A dynamic theory of corporate governance structure. Journal of Institutional and Theoretical Economics, 154, 177-209.

Boot, A., Gopalan, R., \& Taylor, A. V. (2006). The enterpreneur's choice between public and private ownership. Journal of Finance, $61,803-836$.

Boubakri, N., Kooli, M., \& L'Her, J. (2005). Is there life after going public? Evidence from the Canadian market. Journal of Private Equity, 8(3), 30-40.

Boucly, Q., Sraer, D., \& Thesmar, D. (2009). Job creating LBOs. Working Paper. Retrieved 9/5/2018 from http://ssrn.com/abstract=1354087

Buehler, S., Kaiser, C., \& Jaeger, F. (2006). Merge or fail? The determinants of mergers and bankruptcies in Switzerland 1995-2000. Economic Letters, 90(1), 88-95.

Cattaneo, M., Meoli, M., \& Vismara, S. (2015). Financial regulation and IPOs: Evidence from the history of the Italian stock market. Journal of Corporate Finance, 21, 116-131.

Chadha, S. (2003). Do insiders knowingly issue overvalued equity? Evidence from IPOs that get delisted. Working Paper, University of Alabama. Retrieved from https://papers.ssrn.com/sol3/papers.cfm?abstract_id=437441

Chang, J. C., \& Sun, H. L. (2010). Does the disclosure of corporate governance structures affect firms' earnings quality? Review of Accounting and Finance, 9(3), 212-243

Change, X., Lin, S., Tam, L. H., \& Wong, G. (2010). Cross-sectional determinants of post-IPO stock performance: Evidence from China. Accounting and Finance, 50, 581-603.

Chaplinsky, S., \& Ramchand, L. (2012). What drives delistings of foreign firms from US exchanges. Journal of International Financial Markets, Institutions and Money, 22, 1126-1148.

Chemmanur, T. J., \& Fulghieri, P. (1999). A theory of the going-public decision. Review of Financial Studies, 12, $249-279$.

Chemmanur, T. J., He, S., \& Nandy, D. K. (2010). The going-public decision and the product market. Review of Financial Studies, 23, 1855-1908.

Chen, K. C. W., \& Schoderbek, M. P. (1999). The role of accounting information in security exchange delisting. Journal of Accounting and Public Policy, 31(1), 31-57.

Chiraz, D., \& Anis, J. (2013). Corporate governance and delisting risk of French IPO firms. International Review of Management and Business Research, 2(1), 117-127.

Corcanic, A., \& Novak, J. (2015). Earnings management to avoid delisting from a stock market. Working Paper. Retrieved 19/5/2018 from http://ssrn.com/abstract=2557623

Daily, C., \& Dollinger, M. J. (1992). An empirical examination of ownership structure in family and professionally managed firms. Family Business Review, 5(2), 117-1436. 
DeAngelo, H., DeAngelo, L., \& Rice, E. M. (1984). Going private: Minority freezeouts and stockholder wealth. Journal of Law and Economics, 27, 367-401.

Demers, E., \& Joos, P. (2007). IPO failure risk. Journal of Accounting Research, 45(2), 333-371.

De Paola, M., \& Scoppa, V. (2001). The role of family ties in the labour market: An interpretation based on efficiency wage theory. Review of Labour Economics and Industrial Relations, 15, 603-624.

Doidge, C., Karolyi, A., \& Stulz, R. M. (2013). The U.S. left behind? Financial globalization and the rise of IPOs outside the U.S. Journal of Financial Economics, 110, 546-573.

Espenlaub, S., Khurshed, A., \& Mohamed, A. (2012). IPO Survival in a reputational market. Journal of Business Finance and Accounting, 39, 427-463.

Fama, E. F., \& French, K. R. (2004). New lists: fundamentals and survival rates. Journal of Financial Economics, 73, $229-269$.

Fama, E., \& Jensen, M. C. (1983). Separation of ownership and control. Journal of Law and Economics, 73, 229-269.

Franks, J., Mayer, C., Volpin, P., \& Wagner, H. F. (2009). Evolution of family capitalism: A comprehensive study of France, Germany, Italy, and the UK. San Francisco Meetings Paper. Retrieved 24/5/2018 from http://ssrn.com/abstract=1102475

Harris, J. H., Panchapagesan, V., \& Werner, I. M. (2008). Off but not gone: A study of Nasdaq delistings. Working paper, Fisher $\begin{array}{lllll}\text { College } & \text { of } & \text { Business. } & \text { Retrieved } & \text { 18/5/2018 }\end{array}$ https://fisher.osu.edu/academic-departments/department-finance/dice-center/working-papers

Jain, B., \& Jayaraman, N. (1999). The life cycle of initial public offering firms. Journal of Business Finance and Accounting, 26(9-10), 1281-1307.

Jain, B., \& Martin, C. (2005). The association between audit quality and post-IPO performance: A survival analysis approach. Review of Accounting and Finance, 4(4), 50-75.

Jensen, M. C. (1986). Agency costs of free cash flow, corporate finance and takeovers. American Economic Review, 76, $323-329$.

Jensen, M. C., \& Meckling, W. H. (1976). Theory of the firm: Managerial behaviour, agency conflicts and ownership structure. Journal of Financial Economics, 3, 305-360.

Kaplan, S. (1989). The effects of management buy-outs on operations and value. Journal of Financial Economics, 24, $217-254$.

Kaufmann, D., Kraay, A., \& Mastruzzi, M. (2009). Governance Matters VIII Aggregate and Individual Governance Indicators 1996-2008. The World Bank, Development Research Group, Macroeconomics and Growth Team. Retrieved 24/5/2018 from https://ssrn.com/abstract $=1424591$

Kim. W. S. H., \& Weisbach, M. S. (2008). Motivations for public equity offers: an international perspective. Journal of Financial Economics, 87, 281-307.

Kooli, M., \& Meknassi, S. (2007). The survival of US IPO issuers: 1985-2005. Journal of Wealth Management, 10(2), 105-119.

La Porta, R., Lopez-de-Silanes, F., Shleifer, A., \& Vishny, R. W. (1998). Law and finance. Journal of Political Economy, 106, 1113-1155.

La Porta, R., Lopez-de-Silanes, F., \& Shleifer, A. (1999). Corporate ownership around the world. Journal of Finance, 54, $471-517$.

Lazarides, T. (2009). Duality of roles and corporate governance in Greece. Corporate Board: Role, Duties \& Composition, 5(1). Retrieved from https://virtusinterpress.org/IMG/pdf/10-22495_cbv5ilart2.pdf

Lehn, K., \& Poulsen, A. (1989). Free cash flow and shareholder gains in going private transaction. Journal of Finance, 44, $771-787$.

Leland, H., \& Pyle, D. (1977). Information asymmetries, financial structure and financial intermediation. Journal of Finance, 32(2), 371-384.

Leuz, C., Triantis, A., \& Wang, T. Y. (2008). Why do firms go dark? Causes and consequences of voluntary SEC deregistrations. Journal of Accounting \& Economics, 45, 181-208.

Li, J., Zhang, L., \& Zhou, J. (2006). Earnings management and delisting risk of IPO firms. Financial Accounting and Reporting $\begin{array}{llll}\text { Standards } & \text { (FARS) Paper. } & \text { Retrieved } & \text { from }\end{array}$ https://pdfs.semanticscholar.org/8dd2/031e2a1ef7aa11888ec9650bed288d96bbb4.pdf

Loughran, T., \& Ritter, J. (1995). The new issues puzzle. Journal of Finance, 50(1), 23-51.

Macey, J., O'Hara, M., \& Pompilio, D. (2008). Down and out in the stock market: The law and economics of the delisting process. Journal of Law \& Economics, 51(4), 683-713.

Mangena, M., \& Chamisa, E. (2008). Corporate governance and incidences of listing suspension by the JSE Securities Exchange of South Africa: An empirical analysis. The International Journal of Accounting, 43, 28-44.

Marosi, A., \& Massoud, N. (2007). Why do firms go dark? Journal of Financial and Quantitative Analysis, 42, 421-442.

Martinez, I., \& Serve, S. (2011). The delisting decision: The case of buyout offer with squeeze out (BOSO). International Review of Law and Economics, 31(4), 229-239. 
Martinez, I., \& Serve, S. (2016). Reasons for delisting and consequences: A literature review and research agenda. Journal of Economic Surveys, 31(3), 733-770.

Mehran, H., \& Peristiani, S. (2010). Financial visibility and the decision to go private. Review of Financial Studies, 23, $519-547$.

Mellin, L., \& Nordqvist, M. (2000). Corporate governance processes in family firms: The role of influential actors and the strategic arena. Proceedings of ICSB World Conference 2000, 7-10 June, Brisbane, Australia.

Mertzanis, H. V. (2001). Principles of corporate governance in Greece. Corporate Governance: An International Review, 9, 89-100.

Michaely, R., \& Shaw, W. (1995). Does the choice of auditor convey quality in an initial public offering? Financial Management, 24, 15-30.

Mikelson, W. H., Partch, M. M., \& Shah, K. (1997). Ownership and operating performance of companies that go public. Journal of Financial Economics, 44, 281-307.

Mustakallio, M., \& Valcamo, J. (2002). Distinctive challenge of family firms governance: Research findings and practical experiences in Finnish family firms. FBN Annual Conference, 2000, Helsinki, Finland.

Pagano, M., Panetta, F. A., \& Zingales, L. (1998). Why companies go public? An empirical analysis. Journal of Finance, 53, $27-64$.

Peristiani, S., \& Hong, G. (2004). Pre-IPO financial performance and aftermarket survival. Current Issues in Economics and Finance, 10(2), 1-7.

Pour, E. K., \& Lasfer, M. (2013). Why do companies delist voluntary from the stock market? Journal of Banking and Finance, 37, 4850-4860.

Randoy, T., Jensen, J., \& Goel, S. (2003). Family firms and Corporate Governance: Altruism and agency consideration. European Academy of Management Meeting, April 3-5, Milan, Italy.

Renneboog, L., Simons, T., \& Wright, M. (2007). Why do public go private in the UK? The impact of private equity investors, incentive realignment and undervaluation. Journal of Corporate Finance, 13(4), 591-628.

Ritter, J. (1984). The "hot issue" market of 1980. Journal of Business, 57(2), 215-240.

Ritter, J. (1991). The long-run performance of initial public offerings. Journal of Finance, 46(1), 1-27.

Rock, K. (1986). Why new issues are underpriced. Journal of Financial Economics, 34(1), 187-212.

Sanger, P. J., \& Smoller, M. M. (1997). Share price and mortality: an empirical evaluation of newly listed Nasdaq stocks. Journal of Financial Economics, 45, 333-363.

Schary , M. A. (1991). The probability of exit. RAND Journal of Economics, 22(3), 339-353.

Seguin, P. J., \& Smoller, M. M. (1997). Share price and mortality: An empirical investigation of newly listed Nasdaq stocks. Journal of Financial Economics, 45, 333-363.

Serrano, A. (2010). Involuntary delisting in New York and Toronto. Working Paper. Retrieved from http://www.southwesternfinance.org/conf-011/swfa2011_submission_190.pdf

Shleifer, A., \& Vishny, R. W. (1997). A survey of Corporate Governance. Journal of Finance, 52, 737-783.

Spanos, L., Tsipouri, L., \& Xanthakis, M. (2004). Corporate Governance rating and family firms: The Greek case. The Family Firms and Corporate Governance Conference, May 20-22, Instabul, Turkey.

Spathis, C., \& Georgakopoulou, E. (2007). The adoption of IFRS in South Eastern Europe: The case of Greece. International Journal of Financial Services Management, 2(1-2), 50-63.

Stark, O., \& Falk, I. (1998). Transfers, Empathy Formation, and Reverse Transfers. American Economic Review, 88(2), $271-276$.

Teoh, S. H., Wong, T. J., \& Rao, G. R. (1998). Are accruals during Initial Public Offerings opportunistic. Review of Accounting Studies, 3, 175-208.

Thomsen, S., \& Vinten, F. (2007). Delistings in Europe and the costs of governance. Working paper, Copenhagen Business School. Retrieved 9/5/2018 from http://ssrn.com/abstract=986603

Titman, S., \& Trueman, B. (1986). Information quality and the valuation of new issues. Journal of Accounting and Economics, 8(2), 159-172.

Tsipouri, L., \& Xanthakis, M. (2004). Can corporate governance be rated? Ideas based on the Greek experience. Corporate Governance: An International Review, 12(1), 16-28.

Tutino, M., Panetta, I. C., \& Laghi, E. (2013). Key factors in delisting process in Italy: Empirical evidence. GSTF Journal of Business Review (GBR), 2(4), 218-223.

Tzovas, C. (2006). Factors influencing a firm's accounting policy decisions when tax accounting and financial accounting coincide. Managerial Auditing Journal, 21, 372-386.

Vafeas, N., \& Theodorou, E. (1998). The relationship between board structure and firm performance in the UK. British Accounting Review, 30, 383-407. 
Weir, C. M., Laing, D., \& Wright, M. (2005). Undervaluation, private information, agency costs and the decision to go private. Applied Financial Economics, 15, 947-961.

Wagner, S., \& Cockburn, I. (2010). Patents and the survival of Internet related IPOs. Research Policy, 39, 214-228.

Weber, J., \& Willenborg, M. (2003). Do expert information intermediaries add value? Evidence from auditors in Microcap IPOs. Journal of Accounting Research, 41(4), 681-720.

Willenborg, M., \& McKeown, J. (2001). Going-concern initial public offerings. Journal of Accounting and Economics, 30(4), 279-313.

Witmer, J. (2005). Why do firms cross-(de)list? An examination of the determinants and affects of cross-delisting. Working Paper, Bank of Canada. Retrieved 8/5/2018 from https://papers.ssrn.com/sol3/papers.cfm?abstract_id=885503

Yang, S. Y. (2006). Do at-risk firms with good prospects manage accruals to avoid delisting? Working Paper, McCombs School of Business, University of Texas at Austin. https://www.researchgate.net/profile/Zy_Yang2/publication/228700174_Do_At-Risk_Firms_with_Good_Prospects_Manage _Accruals_to_Avoid_Delisting/links/54fb76c30cf2c3f52420494f/Do-At-Risk-Firms-with-Good-Prospects-Manage-Accruals -to-Avoid-Delisting.pdf

Yung, C., Çolak, G., \& Wang, W. (2008). Cycles in the IPO market. Journal of Financial Economics, 89(1), 192-208. 